\title{
Agricultural Biogas Plants as a Chance for the Development of the Agri-Food Sector
}

\author{
Wojciech Czekała' \\ 1 Poznan University of Life Sciences, Wojska Polskiego 28, 60-637 Poznań, Poland \\ e-mail:wojciech@up.poznan.pl
}

\begin{abstract}
Agricultural biogas plants are an important source of energy, where the substrates from agricultural crops can be used. However, these plants need a daily input of biomass in the quantities up to several dozen tons. A few years ago, the most important substrate used for biogas production was maize silage. However, currently, there is a trend to limit the use of the afore-mentioned substrate. This is mainly due to the high cost of the substrate and the conflict over the rational use of valuable soils for biomass production for energy purposes. In the paper, the author undertook the attempts to discuss the possibility of limiting the use of raw vegetable materials for energy production, replacing them with agri-food production waste.
\end{abstract}

Keywords: agri-food sector, food security, waste management, biogas, agricultural biogas plants.

\section{INTRODUCTION}

Renewable energy is an element of each country's economy. The analysis of global trends shows that this direction is and should gradually be developing, mainly due to environmental and economic factors [Safarzyńska and van den Bergh, 2017]. Additionally, in recent years there has been a significant development of agricultural biogas plants in comparison to other renewable energy sources (RES) [Chen and Liu, 2017; Kozłowski et al., 2017]. In Poland, excluding small and micro installations, there are 93 units with a total capacity of approximately $101 \mathrm{MW}$ [http://www.arr.gov.pl], with a tendency of their dynamic development. The investors planning to build a biogas plant have to remember that it is necessary to have the right amount of substrates for proper functioning, with the lowest possible impact on environment, agriculture and the sector itself [Czekała, 2017a; Cieślik et al., 2016]. The purpose of the following work is to analyze the impact of the agricultural biogas plants on the food sector. The author has also attempted to present the areas of activities that could bring benefits for the biogas plant and the agri-food sector.

\section{FOOD VS ENERGY IN RELATION TO AGRICULTURAL BIOGAS PLANT}

Land resources that are suitable for growing crops in most countries are generally limited. This is mainly due to the anthropogenic factors leading to the transformation of agricultural and forest areas into investment ones. Considering the fact that the area dedicated for crops is decreasing, with the simultaneous increase in the demand for food due to the population growth, it is necessary to look for rational solutions allowing to produce food on a global scale [Smith et al., 2017; Voelklein et al., 2017]. Undoubtedly, the most important areas of economy of each country are food security along with energy supply [Kostecka et al., 2017; Moreb et al., 2017]. However, this results, among others, from the necessity of systematic supply of nutrients to the human body in order to function properly. Providing food for all people in the world, whose number is constantly growing and can reach up to 9 billion in 2050-70, constitutes a continuous challenge. With the currently estimated number of around 7 billion, the world experiences a chronic hunger problem, affecting about 2 billion people. Having a similar 
area of arable land, with the ever-increasing human population, it is necessary to boost production potential, both on a local and global scale. That is why the competition in the use of agricultural areas for the production of plants for energy purposes is becoming more and more important.

Biogas plants are type of installations that produce energy in a stable and predictable way [Chatterjee et al., 2017]. Thanks to this, their functioning is not dependent on the weather conditions. In addition, the failure-free biogas plant and the short time of regular maintenance make stable energy production available throughout the year, reaching even $95 \%$ of the theoretical possible production. What is more, the necessary amount of substrates needed to achieve a given power level can be predicted with high probability even for a few years and secure the supply through long-term contracts.

The production of agricultural biogas requires a daily supply of feedstock, namely the substrates for energy production coming from target crops, as well as the increasing by-products and agrofood waste. The first installations in Poland, following the example of the European leader like Germany, most often used maize silage and slurry for the production of agricultural biogas. This was mainly due to the high energy efficiency of maize silage [Kowalczyk-Juśko et al. 2015a]. In the case of Germany, where there are more than 9200 biogas plants, such large amounts of needed substrates may be the cause of some disturbance in the food market. In addition, long-term cultivation of maize in the same fields may pose a major monoculture threat, which is considered unfavorable, among others to the environment, especially soil.

Rama et al., [2013] showed that the agricultural biogas plants are a major competition for the food market, using substrates derived from crop production. With regard to 93 currently functioning biogas plants in Poland, it would be difficult to consider them as competition to food manufacturers, especially taking into account that the biogas market develops slowly but systematically. However, if more installations are built, it will be necessary to ensure a constant supply of significant quantities of substrates [Renewable Energy Law of Poland, 2015; Kowalczyk-Juśko et al. 2015b]. It should be also remembered a wide range of substrates can be used for the production of agricultural biogas, including residues such as beet pulp or fruit and vegetable pomace and waste [Gizińska-Górna et al., 2017; Czekała et al., 2015]. In the case of Germany, in which over 9200 biogas plants mostly use maize silage as feedstock, there is a monoculture threat of cultivation system, causing adverse changes in soil properties. On the other hand, in Poland the maize silage intended for the production of agricultural biogas is only the fourth used feedstock, after slurry, residues from fruits and vegetables, and decomposed waste [http://www.arr.pl]. At the same time, one can observe a decreasing trend of maize in energy production [Kowalczyk-Juśko et al., 2015a]. Under Polish conditions, this is mainly due to the high price of silage, as well as greater attention to alternative sources, which are potentially waste and residues of agri-food origin [Obidziński et al., 2017; Kazimierowicz et al., 2014; Maj et al. 2014; Przybył et al., 2013].

\section{UNUSED FOOD AS A SUBSTRATE FOR BIOGAS PLANTS}

Paradoxically, the crisis on the Polish biogas market in 2013-2016 was the cause of the development of innovative technologies. Investors, who took into consideration the decreasing trend of maize silage utilization in biogas plants, due to monoculture plant cultivation and high costs of obtaining the raw material, started looking for an alternative feedstock for biogas plant and technologies supporting the methane fermentation process.

Poland is a country with a rich agricultural tradition and a very well developed agri-food sector [Chodkowska-Miszczuk and Szymańska, 2013]. Bearing in mind that the creation of waste and by-products is an indispensable element of production processes, it is possible to utilize them for energy production [Sikora et al., 2017]. This mainly concerns unused food of plant origin (Figure 1) e.g. non-graded fruit and vegetables, and process residues, such as fruit pomace or vegetable peels [Smurzyńska et al., 2016].

Utilization of unused plant-derived food for energy production is advisable primarily for two reasons. First of all, the use of these substrates for methane fermentation creates an opportunity to organize waste management in the production plant and in the case of a large installation, even the commune. This is essential to the extent that inadequately deposited waste is generally a source of emissions of harmful gases into the at- 


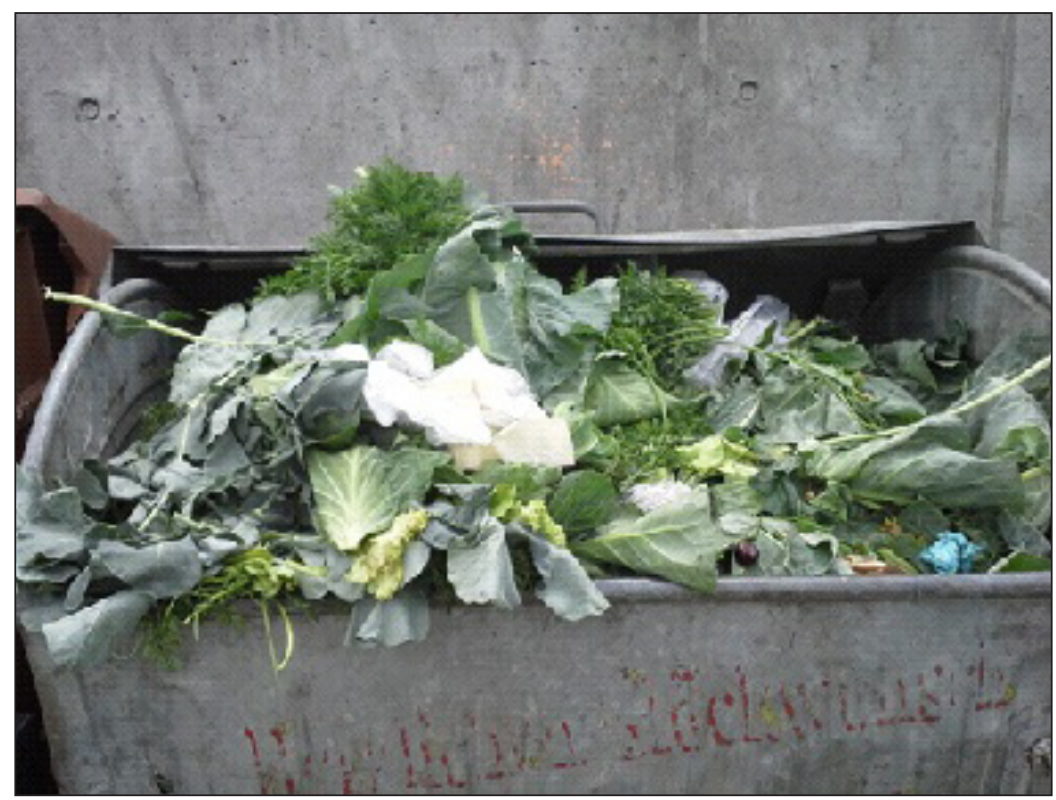

Figure 1. Vegetable food waste in agriculture market

mosphere, such as methane, hydrogen sulphide or ammonia [Cerda et al., 2017]. For this reason, storage of organic waste has not only a negative impact on the environment, but also the energy potential of this waste is lost. The second advantage is that the waste and by-products are free of charge or the cost of obtaining them is generally low. For example, typical residues from vegetable and fruit processing (Figure 2), can be bought by biogas plant owners in Poland for 40-50 PLN per Mg. This amount is about three times lower compared with the costs of maize silage. Having favorable contracts, it is possible to acquire the substrates free of charge, or even to collect fees for their collection, as is the case with the waste from a slaughterhouse.

It should be emphasized that the processing of unused plant-derived substrates can also have a positive impact on the agricultural environment. The main goal here is to limit the land used for the production of plants to be used in biogas generation. By using waste, there is no need to exclude further parts of the area from crop production, which is observed, for example, in the production of maize silage. A positive aspect will also be the ability to produce and utilize a valuable fertilizer, which is the residue of the fermentation process.

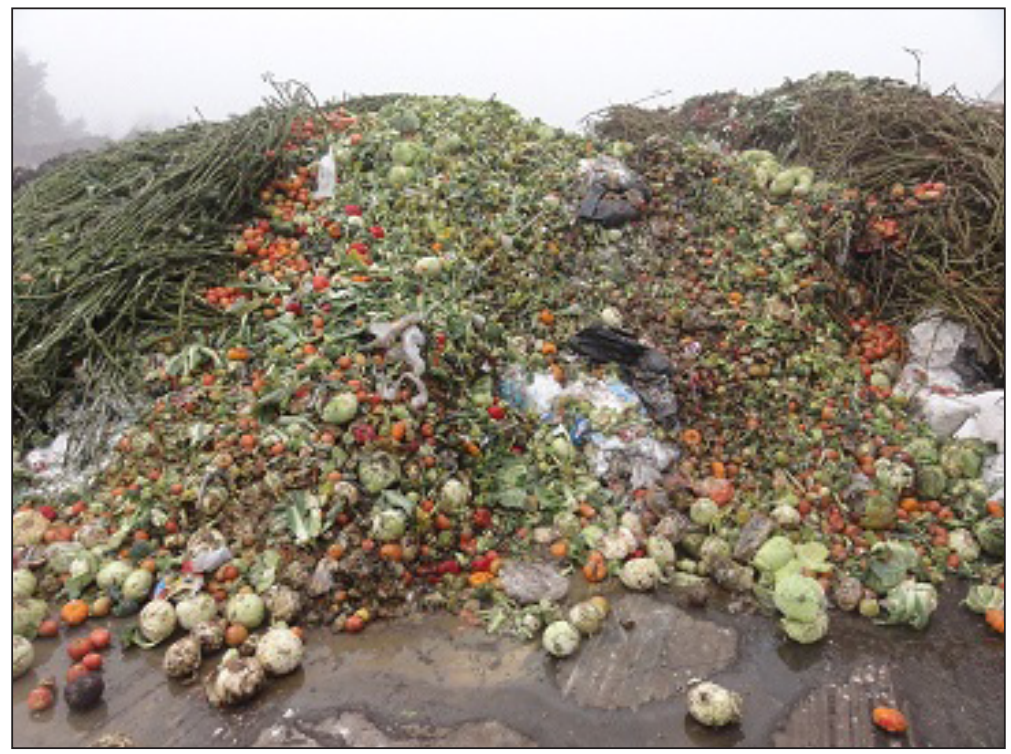

Figure 2. Vegetables and fruits used for the biological conversion 


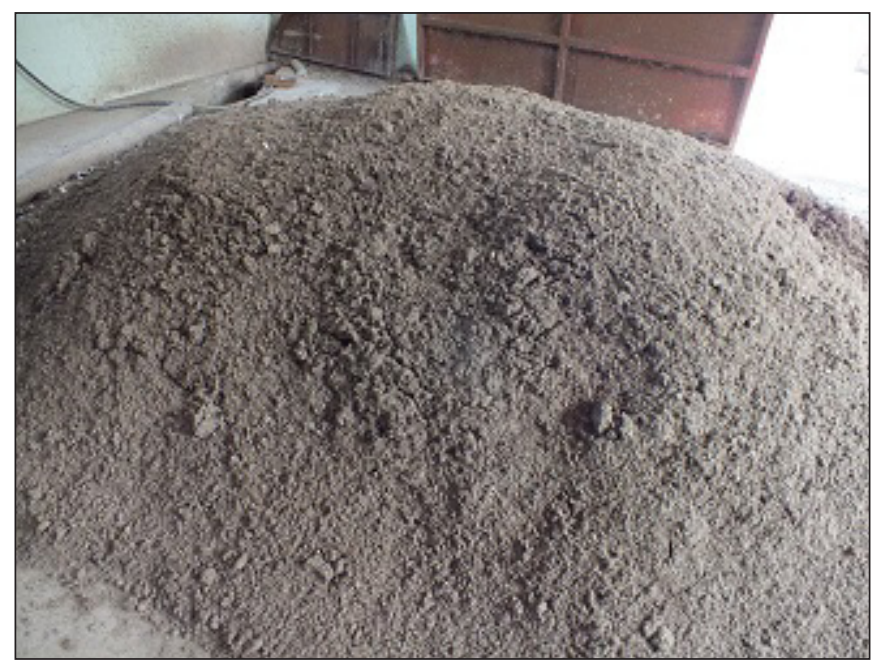

Figure 3. Dried digested pulp in one of the Chinese biogas plants

\section{DIGESTATE FROM AGRICULTURAL BIOGAS PLANT AS A VALUABLE FERTILIZER}

The main product of the methane fermentation process is biogas [Dach et al., 2016] in which the dominant component is methane, i.e. an energy gas. However, one should remember about the second basic product, i.e. the digestated pulp [Czekała et al., 2012] as an important aspect of post-fermentation management. The production of the pulp constitutes on average around $85 \%$ of the biogas plant feed load. For example, for a typical agricultural biogas plant with a capacity of $1 \mathrm{MW}$, this will translate into several dozen $\mathrm{Mg}$ per day. In the early period of agricultural biogas plant formation, the digestate was generally treated as an unwanted waste, causing a problem for plant owners. Over time, the resulting waste began to be appreciated and utilized as a product due to its properties, especially fertilizers [Ciesielczuk et al., 2017; Czekala et al., 2017b]. The digestated pulp is characterized by a fluid state of aggregation and a high concentration of nutrients for plants. As a result, more and more biogas plant owners are trying to certify their digestate as a valuable fertilizer or a soil conditioner, which allows the product to be marketed (Figure 3 ). The study conducted, among others at Poznan University of Life Sciences, Warsaw University of Life Sciences and University of Life Sciences in Lublin, confirm the suitability of digestate, especially in plant production. In turn, this creates the possibility of limiting the financial outlays on mineral fertilizers, which are comparable.

\section{CONCLUSION}

The supply of food and energy seems to be the greatest issue of humanity at the present time. For this reason, the agricultural biogas plants use a wide range of substrates cultivated on purpose, as well as by-products and waste in order to produce biogas. In turn, the production of biogas allows the generation of electricity and heat, the consequence of which is the reduction of the amount of fossil fuels being extracted and processed. Using waste in the agricultural biogas plants in question is a favorable solution. This will allow, first and foremost, to organize waste management within the plant or a given area, and eliminate the conflict in the food - energy system in the context of full-value agricultural products. At the same time, these activities are extremely important in terms of environmental protection.

\section{Acknowledgements}

This study was performed in the frame of the IN OIL project: An innovative method for bioconversion of by-products from food processing industry that was financed by the National Centre for Research and Development within the Lider VII Programme LIDER/5/0148/L-7/15/NCBR/2016 .

\section{REFERENCES}

1. Chatterjee P., Ghangrekar M.M., Rao S. 2017. Biogas Production from Partially Digested Septic Tank Sludge and its Kinetics. Waste and Biomass Valorization, 1-12. 
2. Cerda A., Artola A., Font X., Barrena R., Gea T., Sánchez A. 2018. Composting of food wastes: Status and challenges. Bioresource Technology, 248, 57-67.

3. Chen Q., Liu T.: Biogas system in rural China. 2017. Upgrading from decentralized to centralized?. Renewable and Sustainable Energy Reviews, 78, 933-944.

4. Chodkowska-Miszczuk, Szymańska A.: Agricultural biogas plants - A chance for diversification of agriculture in Poland. 2013. Renewable and Sustainable Energy Reviews, 20, 514-518.

5. Ciesielczuk T., Poluszyńska J., Rosik-Dulewska C. 2017. Homemade slow-action fertilizers, as an economic solution for organic food production. Journal of Ecological Engineering 18(2), 78-85.

6. Cieślik M., Dach J., Lewicki A., Smurzyńska A., Janczak D., Pawlicka-Kaczorowska J., Boniecki P., Cyplik P., Czekała W., Jóżwiakowski K. 2016. Methane fermentation of the maize straw silage under meso- and thermophilic conditions. Energy, 115(2), 1495-1502.

7. Czekała W., Pilarski K., Dach J., Janczak D., Szymańska M. 2012. Analysis of management possibilities for digestate from biogas plant. Technika Rolnicza Ogrodnicza Leśna, 4, 13-15.

8. Czekała W., Kozłowski K., Dach J., Boniecki P., Lewicki A., Janczak D., Jóźwiakowski K., Piechota T. 2015. Energy Conversion from Biomass to Hydrogen and Methane. 4th International Conference on Materials Engineering for Advanced Technologies (ICMEAT) London, June 27-28, 2015, 654-657.

9. Czekała W. 2017a. Concept of IN-OIL project based on bioconversion of by-products from food processing industry. Journal of Ecological Engineering, 18(5), 180-185.

10. Czekała W., Dach J., Dong R., Janczak D., Malińska K., Jóźwiakowski K., Smurzyńska A., Cieślik M. 2017b. Composting potential of the solid fraction of digested pulp produced by a biogas plant. Biosystems Engineering 160, 25-29.

11. Dach J., Koszela K., Boniecki P., Zaborowicz M., Lewicki A., Czekała W., Skwarcz J.,Wei Q. Piekarska-Boniecka H., Białobrzewski I. 2016. The use of neural modelling to estimate the methane production from slurry fermentation processes. Renewable and Sustainable Energy Reviews, 56, 603-610.

12. Gizińska-Górna M., Czekała W., Jóźwiakowski K., Lewicki A., Dach J., Marzec M., Pytka A., Janczak D., Kowalczyk-Juśko A., Listosz A. 2016. The possibility of using plants from hybrid constructed wetland wastewater treatment plants for energy purposes. Ecological Engineering, 95, 534-541.

13. http://www.kowr.gov.pl/uploads/pliki/oze/ biogaz/7.\%20Rejestr\%20wytw\%C3\%B3rc\% C3\%B3w\%20biogazu\%20rolniczego\%20z\%20 dnia $\% 2005.01 .2018 \% 20$ r..pdf, access on 5th, January 2018

14. Kazimierowicz J. 2014. Organic waste used in ag- ricultural biogas plants. Journal of Ecological Engineering, 15(2), 88-92.

15. Kowalczyk-Juśko A., Kościk B., Jóźwiakowski K., Marczuk A., Zarajczyk J., Kowalczuk J., Szmigielski M., Sagan A. 2015a. Effects of biochemical and thermochemical conversion of sorghum biomass to usable energy. Przemysł Chemiczny, 94(10), 1838-1840.

16. Kowalczyk-Juśko A., Kościk B., Jóźwiakowski K., Marczuk A., Zarajczyk J., Kowalczuk J., Szmigielski M., Sagan A. 2015b. Effects of biochemical and thermochemical conversion of sorghum biomass to usable energy. Przemysł Chemiczny, 94(10), 1838-1840.

17. Kozłowski K., Lewicki A., Cieslik M., Janczak D., Czekała W., Smurzyńska A., Brzoski M. 2017. The possibility of improving the energy and economic balance of agricultural biogas plant. Technika Rolnicza Ogrodnicza Leśna, 3, 10-13.

18. Maj G., Piekarski W., Kowalczyk-Juśko A., Łukaszczyk A. 2014. Waste from agri-food sector, communal and targeted crops as a source of biogas. Przemysł Chemiczny, 93(5), 732-736.

19. Moreb N.A., Priyadarshini A., Jaiswal A.K. 2017. Knowledge of food safety and food handling practices amongst food handlers in the Republic of Ireland. Food Control, 80, 341-349.

20. Obidziński S., Joka M., Fijoł O. 2017. Two-stage agglomeration of fine-grained herbal nettle waste. Int. Agrophys., 31, 515-523.

21. Przybył J., Kot W., Wojcieszak D., Mioduszewska N., Durczak K. 2013. Biogas yield of maize straw. Agricultural Enginerring 4(148), 103-111.

22. Rama R., Borowski S., Dulcet E. 2013. Biogas from agricultural biogas plants - competition for food market. Inż. Ap. Chem., 52(2), 60-61.

23. Renewable Energy Law of Poland [Dz.U. 2015 poz. 478]

24. Safarzyńska K., van den Bergh J.C.J.M. 2017. Financial stability at risk due to investing rapidly in renewable energy. Energy Policy, 108, 12-20.

25. Sikora J., Niemiec M., Szeląg-Sikora A., Kuboń M., Olech E., Marczuk A. 2017. Biogasification of wastes from industrial processing of carps. Przemysł Chemiczny, 96(11), 2275-2278.

26. Smurzyńska A., Czekała W., Lewicki A., Cieślik M., Kozłowski K., Janczak D. 2016. The biogas output of vegetables utilized in the polish market due to the introduction of the Russian embargo (in Polish). Technika Rolnicza Ogrodnicza Leśna 6, 24-27.

27. Smith M.D., Rabbitt M.P., Coleman- Jensen A. 2017. Who are the World's Food Insecure? New Evidence from the Food and Agriculture Organization's Food Insecurity Experience Scale. World Development, 93, 402-412.

28. Voelklein M.A., Shea R.O., Jacob A., Murphy J.D. 2017. Role of trace elements in single and twostage digestion of food waste at high organic loading rates. Energy, 121, 185-192. 